Wells, P. R. A. 1977: Pyroxene thermometry in simple and complex systems. Contr. Miner. Petrol. 62, 129-140.

Wood, B. J. \& Banno, S. 1973: Garnet-orthopyroxene and orthopyroxene-clinopyroxene relationships in simple and complex systems. Contr. Miner. Petrol. 42, 109-124.

Department of Geology, Portsmouth Polytechnic, Burnaby Road, Portsmouth POI $3 Q L$, U.K.

\title{
Evidence of mid-Proterozoic granite formation in the Isua area
}

\section{F. Kalsbeek, D. Bridgwater and J. Boak}

A 1.5-2 $\mathrm{m}$ wide fine-grained undeformed acid dyke, cutting the Early Archaean Isua supracrustal succession, was found in 1978 (D.B., J.B.). Preliminary Rb-Sr isotope measurements (F.K.) of small hand samples suggested an unexpected mid-Proterozoic age. Additional material was collected in 1979 (J.B.). Owing to weight restrictions in the helicopter, some of the samples are smaller (100-500 g) than we would normally use, but we feel justified in presenting the results since they suggest Proterozoic granitic activity in the area, which has implications for the later history of the Archaean block.

The dyke outcrops on a small knoll in the supracrustal belt $3.5 \mathrm{~km}$ due SW of the Kryolitselskabet's camp at Isukasia. It has a slightly irregular strike trending approximately N-S vertical and is sharply discordant to the NE-SW vertical trend of the country rocks. The dyke can be followed for 20-30 m before being covered by snow and gravel; no continuation is seen along strike. We have not noted other examples of such dykes in the area. No intersections with the major Proterozoic basic dykes are seen.

The country rocks to the dyke are inhomogeneous amphibolite and chlorite schists with local calcareous units, one of which forms the knoll on which the dyke occurs. There are occasional thin biotite-rich layers in the amphibolite. The margins to the dyke are sharp and slightly finer grained than the dyke centres with small fragments of country rock enclosed locally in the marginal few centimetres. Although the margins are chilled there is local reaction between dyke and country rock on a microscopic scale, so at the actual contact there is a mixed zone $2-3 \mathrm{~mm}$ wide with fragments of biotite-rich country rock forming recrystallised patches in dyke matrix. Away from the marginal $3-4 \mathrm{~cm}$ there are no inclusions.

The dyke rock is very dark purple-brown at the margins becoming slightly lighter in colour near the centre. It breaks like flint and shows plagioclase phenocrysts $1-2 \mathrm{~mm}$ in diameter, which are more noticable near the margin due to the contrast with the finer grained matrix. In section the dyke consists of fine-grained $(0.05 \mathrm{~mm})$ quartz, biotite, muscovite and both plagioclase and $\mathrm{K}$-feldspar with accessory zircon and sphene. There are phenocrysts and aggregates of oligoclase and partly resorbed quartz and occasional biotite aggregates. The centre of the dyke contains some opaque minerals, partly replaced by sphene. The pheno- 
crysts in the margin are fresh; nearer the dyke centres they are commonly slightly altered and there is calcite in the groundmass.

The rock has a normal granitic chemistry (Table 4) with slightly higher $\mathrm{K}_{2} \mathrm{O}$ and $\mathrm{K} / \mathrm{Na}$ ratios in the centre. There is no chemical evidence of major element contamination by country rock in the material studied.

The $\mathrm{Rb} / \mathrm{Sr}$ and ${ }^{87} \mathrm{Sr} /{ }^{86} \mathrm{Sr}$ ratios were measured at the Institute of Petrology, University of Copenhagen, following analytical techniques described by Kalsbeek et al. (1978). The age calculation was done by the McIntyre method (McIntyre et al., 1966) using $\lambda^{87} \mathrm{Rb}=$ $1.42 \times 10^{-11}$ year $^{-1}$. The analytical results of the six samples measured are given in Table 4 and displayed in fig. 24. Errors are at the $2 \sigma$ level.

In the ${ }^{87} \mathrm{Sr} /{ }^{86} \mathrm{Sr}-{ }^{87} \mathrm{Rb} /{ }^{86} \mathrm{Sr}$ diagram (fig. 24 ) the samples plot close to a $1610 \pm 130 \mathrm{~m} . \mathrm{y}$. isochron with initial ${ }^{87} \mathrm{Sr} /{ }^{86} \mathrm{Sr}$ ratio $0.766 \pm 0.012$ and an MSWD 10.4. The rather high MSWD value may be due to the small size of several of the samples - in two instances about $100 \mathrm{~g}$. However, the rock is fine grained which makes the use of large samples less critical. Due to the wide spread in ${ }^{87} \mathrm{Rb} /{ }^{86} \mathrm{Sr}$ ratios, the slope of the best-fit line is well defined and hardly depends on which of the McIntyre calculation models is used. Provisionally, we interpret the $1610 \mathrm{~m} . \mathrm{y}$. age as close to the time of intrusion of the dyke, because there is little evidence of later metamorphism and deformation of the dyke rock.

Both the high initial ${ }^{87} \mathrm{Sr} /{ }^{86} \mathrm{Sr}$ ratio $(0.766)$ and the eu-granitic chemistry are consistent

Table 4. Chemical and isotopic composition of granite dyke, Isua

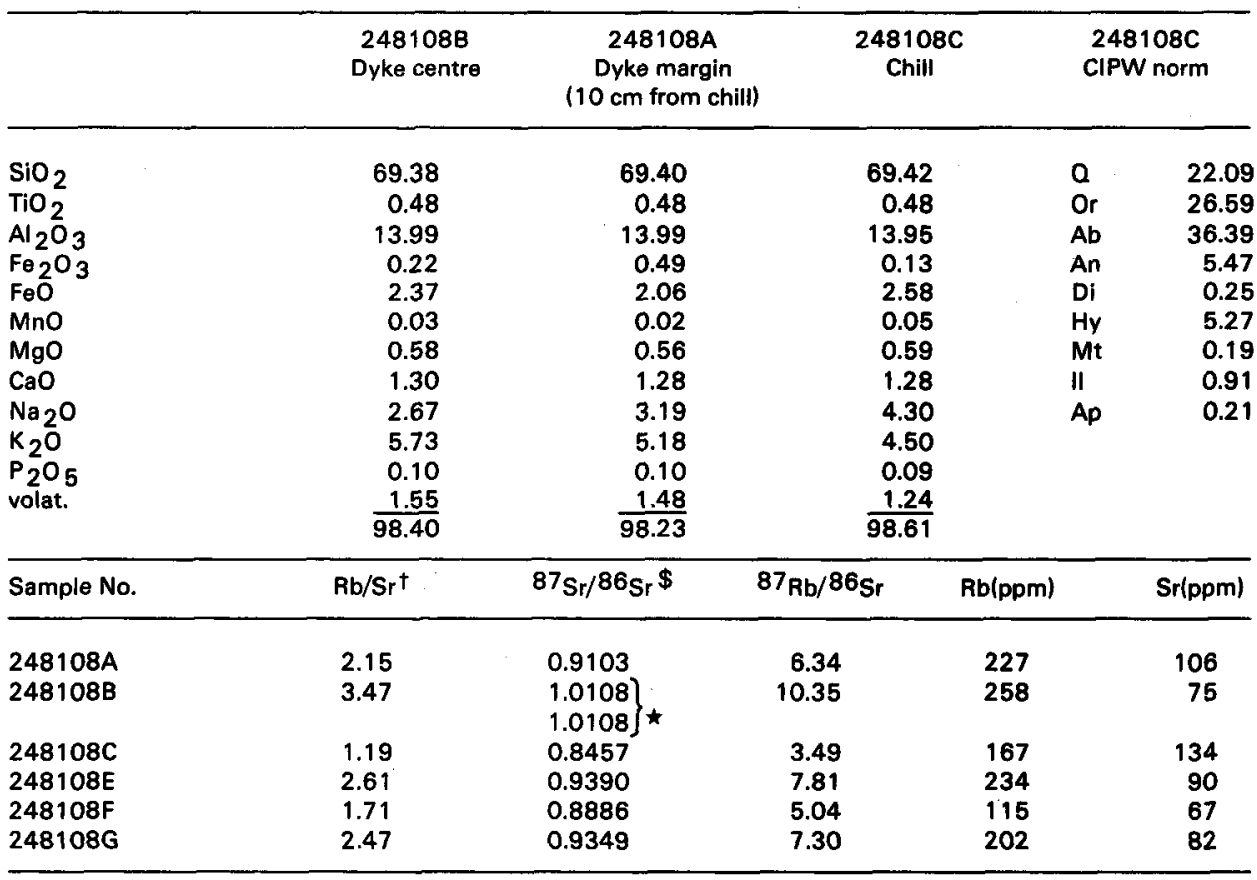

2 determinations on different Sr separations.

Relative to $\mathrm{G}-2=0.355$. Precision $\pm 1.5 \%(2 \sigma)$.

$\$$ Normalised and relative to Eimer \& Amend $\mathrm{SrCO}_{3}=0.7080$. Precision $\pm 0.0005(2 \sigma)$. 
Fig. 24. Isochron diagram for samples of a granitic dyke at Isua.

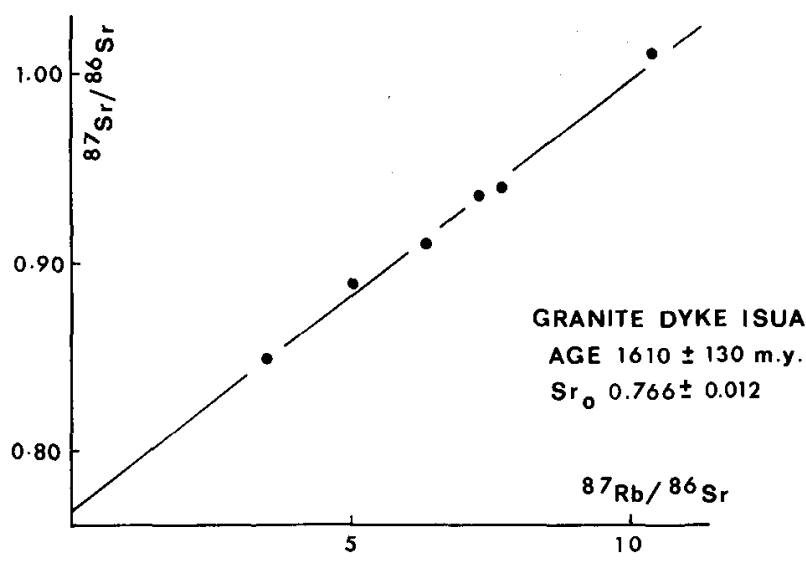

with an anatectic crustal origin of the rock. The source rock may have been the c. 3800 m.y. old Amitsoq-type gneisses or possibly the supracrustal rocks that occur within the gneisses. Judging by the increase in ${ }^{87} \mathrm{Sr} /{ }^{86} \mathrm{Sr}$ ratio in the interval between $3800 \mathrm{~m}$.y. and $1600 \mathrm{~m} . \mathrm{y}$. from 0.700 to 0.766 , the average $\mathrm{Rb} / \mathrm{Sr}$ ratio in the source rocks can be estimated to have been approximately 0.70 . This is higher than mean values from the Amitsoq gneisses in the Isua area and could suggest that relatively $\mathrm{Rb}$-rich supracrustals were involved.

Granitic activity of this age has not been reported from the Archaean craton in Greenland, the nearest known mid-Proterozoic granite intrusion being the granites of the Ketilidian fold belt $450 \mathrm{~km}$ to the south or the almost equidistant 1550-1600 m.y. granites of the Nagssugtoqidian of East Greenland. Proterozoic thermal activity is however known to have occurred in the Archaean rocks of the Godthåb-Isua area from $\mathrm{Rb}-\mathrm{Sr}$ and $\mathrm{K}$-Ar mineral age studies (Lambert \& Simons, 1969; Pankhurst et al., 1973; Baadsgaard et al., 1976). The presence of a Proterozoic granite dyke at Isua indicates that high temperatures were reached at least locally at depth in the Archaean crust during the Proterozoic.

\section{References}

Baadsgaard, H., Lambert, R. St. J. \& Krupicka, J. 1976: Mineral isotopic age relationships in the polymetamorphic Amitsoq gneisses, Godthaab District, West Greenland. Geochim. cosmochim. Acta 40, 513-527.

McIntyre, G. A., Brooks, C., Compston, W. \& Turek, A. 1966: The statistical assessment of Rb-Sr isochrons. J. geophys. Res. 71, 5459-5468.

Kalsbeek, F., Bridgwater, D. \& Zeck, H. P. 1978: A 1950 60 Ma Rb-Sr whole-rock isochron age from two Kangâmiut dykes and the timing of the Nagssugtoqidian (Hudsonian) orogeny in West Greenland. Can. J. Earth Sci. 15, 1122-1128.

Lambert, R. St. J. \& Simons, J. G. 1969: New K/Ar age determinations from southern West Greenland. Rapp. Grønland geol. Unders. 19, 68-71.

Pankhurst, R. J., Moorbath, S., Rex, D. C. \& Turner, G. 1973: Mineral age patterns in ca. 3700 my old rocks from West Greenland. Earth planet. Sci. Lett. 20, 157-170. 